\title{
AZ AGRESSZÍV ADÓTERVEZÉSI STRUKTÚRÁKRA VONATKOZÓ NEMZETKÖZI ADÓÜGYI INFORMÁCIÓCSERE, KÜLÖNÖS TEKINTETTEL AZ UNIÓS SZABÁLYOZÁSRA
}

International Exchange of Tax Information Regarding Agressive Tax Planning Structures, With Special Regard to the EU Legislation

\section{Varga Erzsébet ${ }^{1}$}

\begin{abstract}
Absztrakt: Az információcsere kiterjesztése az agresszív adótervezési struktúrákra az automatikus információcsere egyik legújabb fejleménye, mely jól illeszkedik a nemzetközi adóügyi információcsere bővítésének elmúlt évtizedekben zajló folyamatába. Az információcsere újabb előrelépést jelent a nemzetközi adóelkerülés elleni küzdelemben, és lehetőséget teremt az adóhatóságok számára a még hatékonyabb kockázatelemzésre. Az alapul szolgáló közösségi szabályozás mindemellett több bizonytalansági tényezőt tartalmaz, mely csökkentheti az információcsere hatékonyságát, és növelheti az érintett gazdasági szereplők jogszabály-megfelelési költségeit.
\end{abstract}

Kulcsszavak: információcsere; automatikus adóügyi információcsere; határon átnyúló konstrukció; DAC6 jelentéstétel; agresszív adótervezés; BEPS

Abstract: Extending the exchange of information to agressive tax planning structures is one of the latest developments in automatic exchange of

${ }^{1}$ Dr. Varga Erzsébet a PPKE-JÁK, Pénzügyi Jogi Tanszék megbízott oktatója. Kutatási területei különösen a nemzetközi adóügyi információcsere, a digitális vállalkozások adózása, valamint a BEPS. Több mint tíz éve vesz részt az egyetemi oktatásban különböző egyetemeken. Email: varga.erzsebet@jak.ppke.hu

ORCID: https://orcid.org/0000-0002-4643-052X

A szerző további munkásságát lásd a Magyar Tudományos Művek Tára oldalán: https: $/ / \mathrm{m} 2 . \mathrm{mtmt} \cdot \mathrm{hu} /$ gui2/?type $=$ authors\&mode=browse\&sel $=10044251 \& v i e w=$ dataSheet 
information and is in line with recent years' progress to increase tax information exchange at international level. The exchange of information is a new element in combatting international tax avoidace and helps tax authorities to carry out more effective risk assessment of taxpayers. The underlying EU legislation contains various uncertainties however, which may undermine the efficiency of information exchange and increase compliance costs for economic players involved.

Keywords: information exchage; automatic exchange of tax information; cross-border arrangements; DAC6 reporting; agressive tax planning; BEPS

\section{BEVEZETÉS}

Az elmúlt évtizedekben egyre elterjedtebbé váltak azok a nemzetközi adótervezési struktúrák, amelyek segítségével a multinacionális vállalatok olyan országokba csoportosították jövedelmeiket, ahol kedvezőbb az adóterhelés. Ezzel egyidejûleg a költségeket olyan országokba csatornázták, ahol magasabb az adóteher, így a magasabb költségeket használták fel az adóalap csökkentésére. Az említett adótervezési megoldások rendszerint összhangban vannak az alapul szolgáló nemzeti és nemzetközi adójogszabályok szövegével, ugyanakkor jelentős károkat okozhatnak a nemzeti költségvetéseknek.

Az automatikus adóügyi információcsere elsősorban ezen káros nemzetközi gyakorlatok visszaszorítására született. ${ }^{2} \mathrm{Az}$ automatikus információcsere keretében a nemzeti adóhatóságok rendszeres időközönként, külön megkeresés nélkül továbbítanak adatokat egymás részére, előre meghatározott információkról. ${ }^{3}$ A nemzetközi adózási gyakorlatban ma már számos jogi dokumentum teszi lehetôvé az automatikus információcserét: a kettôs adóztatás elkerülésére irányuló egyezmények mellett az OECD BEPS eredményeként elfogadott többoldalú nemzetközi megállapodások, valamint az EU-n belül kialakított közigazgatási együttmúködési szabályok tartalmaznak az automatikus adóügyi információcserét szolgáló rendelkezéseket.

Az automatikus adóügyi információcsere egyik legújabb formája az ún. „határon átnyúló konstrukciókra” vonatkozó nemzetközi informá-

\footnotetext{
2 OECD, 2012. 19. o.

3 Manual on the Implementation of Exchange of Information for TAX PURPOSES, 2006.
} 
ciócsere, amelynek célja, hogy a potenciálisan agresszív adótervezési konstrukciókat az adóhatóságok könnyebben feltárhassák, és azokra a lehető legrövidebb időn belül reagáljanak. Az információcsere azáltal valósulhat meg, hogy az adótervezésben közremúködők - adótanácsadók, ügyvédek, stb. - kötelesek meghatározott ügyletekre vonatkozó adatokat jelenteni saját adóhatóságuk fel, mely adatokat aztán az adóhatóságok automatikusan továbbítanak a többi érintett tagállami adóhatóság felé.

Az agresszív adótervezési konstrukciókra vonatkozó automatikus információcsere jelenleg kötelező érvénnyel érvényesül az EU tagállamok adóhatóságai között, az adózás területén történő közigazgatási együttmúködésről szóló 2011/16/EU irányelv ${ }^{4}$ (a továbbiakban: Közigazgatási Együttmúködési Irányelv vagy DAC) keretében kialakított együttműködésre tekintettel. Az információcsere ezen formáját a DAC egyik módosítása ${ }^{5}$ vezette be, amely DAC 6 elnevezéssel vált közismertté (a továbbiakban: DAC 6). A DAC 6 a 2018. június 25-ét követően végre-hajtott, meghatározott ismertetőjegyekkel rendelkezô konstrukciók esetére írja elô az adótervezésben közreműködők kötelező jelentéstételét és az erre épülő adóhatóságok között információcserét.

Jelen tanulmány célja az agresszív adótervezési struktúrákra vonatkozó információcserében rejlő lehetôségek feltárása, és jogalkalmazás során felmerülő gyakorlati problémák felvetése. Hipotézisünk az, hogy bár az információcsere fontos új eszközt ad az adóhatóságok kezébe, a jelentéstétel jelentős többlet-erőforrásokat és többletköltségeket kíván meg a végrehajtásban résztvevő gazdasági szereplőktől, és még inkább felerősíti az igényt az adózói jogok hatékony védelmére. Az automatikus adóügyi információcsere hatékony és elengedhetetlen eszköz a nemzetközi adóelkerülés visszaszorítására, ugyanakkor nem eredményezheti azt, hogy a jogszerűen és jóhiszeműen eljáró adózók viselnek aránytalan többletterheket. A helyes egyensúly csak egyértelmú nemzetközi szintû jogalkotás és egységes nemzetközi joggyakorlat révén valósulhat meg.

4 A TANÁCS 2011/16/EU IRÁNYELVE az adózás területén történő közigazgatási együttmûködésről és a 77/799/EK irányelv hatályon kívül helyezéséről, HL L 64, 2011.3.11.

5 A TANÁCs (EU) 2018/822 IRÁNYELVE a 2011/16/EU irányelvnek az adatszolgáltatási kötelezettség alá tartozó, határokon átnyúló konstrukciókkal kapcsolatosan az adózás területére vonatkozó kötelező automatikus információcserére vonatkozó előírásainak módosításáról. 


\section{A HATÁRON ÁTNYÚLÓ KONSTRUKCIÓKRA VONATKOZÓ INFORMÁCIÓCSERE AZ EU KÖZIGAZGATÁSI EGYÜTTMÜKÖDÉS RENDSZERÉBEN}

A DAC 6 szerinti jelentéstételi kötelezettség az Európai Unión belül jelenleg a Közigazgatási Együttmúködési Irányelv keretében valósul meg. A Közigazgatási Együttmúködési Irányelv volt az első olyan jogi dokumentum, mely széles körben ad lehetôséget a nemzetközi adóügyi információcserére. ${ }^{6} \mathrm{Az}$ irányelv az automatikus adatátadás lehetőségét fokozatosan terjesztette ki 2015-től kezdődően, vagyis folyamatosan bővült azon adózói információk köre, melyeket a tagállami adóhatóságok megosztanak egymással. Kezdetben az adatcsere csak a magánszemélyek egyes jövedelmeire terjedt ki (munkaviszonyból származó jövedelem, igazgatósági tiszteletdíj, életbiztosítási termékekből származó jövedelem, nyugdíj és ingatlanból származó jövedelem), majd kibővült a pénzügyi számlainformációk körére (DAC 2). Ezt követte később az információcsere az adómegállapítási határozatok (DAC 3) ${ }^{7}$, az országonkénti - transzferár jelentések (DAC 4) ${ }^{8}$, és a pénzmosási adatok (DAC 5) terén. Ebbe a folyamatba illeszthető a DAC 6, mely a határon átnyúló adótervezési konstrukciókra bővíti az adatátadás körét.

$\mathrm{Az}$ adóügyi információcsere Közigazgatási Együttmúködési Irányelvben foglalt szabályait Magyarországon az adó- és egyéb közterhekkel kapcsolatos nemzetközi közigazgatási együttmúködés egyes szabályairól szóló 2013. évi XXXVII. törvény (a továbbiakban: Aktv.) ültette át a hazai jogba, mely az elmúlt évek során folyamatosan követte le az irányelv módosításait. A határon átnyúló konstrukciók bejelentésére és cseréjére vonatkozó Aktv. szabályok 2020. július 1-étôl léptek hatályba.

Az alábbi táblázat röviden összefoglalja, hogy a magyar adóhatóság milyen adatokról, mikortól cserél adatokat más tagállamok adóhatóságaival a Közigazgatási Együttműködési Irányelv alapján:

${ }^{6}$ VARGA, 2019. 406. o.

7 A TANÁCS 2015/2376 IRÁNYELVE a 2011/16/EU irányelvnek az adózás területére vonatkozó kötelező automatikus információcsere tekintetében történő módosításáról, HL L 332, 2015.12.18.

8 A TANÁCS 2016/881/EU IRÁNYELVE a 2011/16/EU irányelvnek az adózás területére vonatkozó kötelező automatikus információcsere tekintetében történő módosításáról.

9 ÖRY, 2016. 


\begin{tabular}{|c|c|c|c|}
\hline Cserélt adat & Jogalap & $\begin{array}{c}\text { Adatok } \\
\text { elérhetősé } \\
\text { ge }\end{array}$ & $\begin{array}{c}\text { Adatcsere } \\
\text { kezdete }\end{array}$ \\
\hline \multicolumn{4}{|l|}{$\begin{array}{l}\text { Magánszemélyek } \\
\text { jövedelmei }\end{array}$} \\
\hline Kamat & $\begin{array}{c}\text { Megtakarítási } \\
\text { Irányelv/DA } \\
\text { C } \\
\end{array}$ & $\begin{array}{c}2005.01 .01 . \\
-\end{array}$ & $2005 / 2016$ \\
\hline $\begin{array}{l}\text { Munkaviszony, vezető } \\
\text { tisztségviselő, nyugdíj, } \\
\text { ingatlan, biztosítás }\end{array}$ & $\mathrm{DAC}$ & $\begin{array}{c}2014.01 .01 . \\
-\end{array}$ & 2015 \\
\hline $\begin{array}{l}\text { Pénzügyi } \\
\text { számlainformációk }\end{array}$ & DAC 2 & $\begin{array}{c}2016.01 .01 . \\
-\end{array}$ & 2017 \\
\hline $\begin{array}{l}\text { Feltételes } \\
\text { adómegállapítás, előzetes } \\
\text { ármegállapítás }\end{array}$ & DAC 3 & $\begin{array}{c}2012.01 .01 . \\
-\end{array}$ & 2017 \\
\hline Országonkénti jelentések & DAC 4 & $\begin{array}{c}2016.01 .01 . \\
-\end{array}$ & 2018 \\
\hline Pénzmosási adatok & DAC 5 & $\begin{array}{c}2018.01 .01 . \\
-\end{array}$ & 2018 \\
\hline $\begin{array}{l}\text { Határon átnyúló } \\
\text { konstrukciók }\end{array}$ & DAC 6 & $\begin{array}{c}2018.06 .25 . \\
-\end{array}$ & 2021 \\
\hline
\end{tabular}

1. sz. táblázat: A DAC szabályozás alapján automatikus információcsere keretében Magyarország által cserélt adóügyi információk; Forrás: saját szerkesztés

Az automatikus információcserében résztvevő magyar hatáskörrel rendelkező hatóság a NAV Központi Kapcsolattartó Irodája, mely automatikus információcsere keretében továbbítja más tagállam hatáskörrel rendelkező hatósága részére a Közigazgatási Együttműködési Irányelvben meghatározott jövedelem adatokat.

\subsection{A jelentéstételi kötelezettség alkalmazási köre}

A DAC 6 tárgyi hatálya széles körű, a hozzáadott értékadó (áfa), a vám, a jövedéki adó és a társadalombiztosítási járulékok kivételével 
valamennyi adónemre kiterjed. ${ }^{10}$ A széles alkalmazási körből az is következik, hogy a DAC 6 hatálya azon speciális adókra (például digitális társaságok árbevételét terhelő adók) is alkalmazható, melyek a közvetett adókra jellemző beszedési mechanizmusra épülnek. A gyakorlatban mégis arra lehet számítani, hogy a DAC 6 elsősorban a közvetlen adók területét fogja érinteni, mivel az agresszív adótervezés körében tartozó adótervezési konstrukciók tipikusan a jövedelemadókat (személyi jövedelemadó, társasági adó), a tőke-nyereségadót, osztalékadót, örökösödési adót (öröklési illetéket), helyi adókat, vagyonadókat fogja érinteni.

A DAC 6 tárgyi hatálya kizárólag a határon átnyúló konstrukciókra terjed ki, azaz a belföldi struktúrákra föszabályként nem vonatkozik. A DAC 6 szabályozás ugyanakkor megengedi, hogy a tagállamok a nemzetközi elemekkel rendelkező konstrukciókhoz hasonló adatszolgáltatási intézkedéseket foganatosítsanak a belföldi struktúrákra is, azzal, hogy a kapcsolódó információkat a tagállami adóhatóságok nem osztják meg automatikusan más tagállamok illetékes hatóságaival. Az ilyen információk kérésre, vagy spontán módon kerülhetnek átadásra, megfelelő jogalap alapján. Az uniós gyakorlatban vannak olyan tagállamok, melyek kifejezetten éltek ezzel a lehetôséggel ${ }^{11}$, a magyar szabályozás nem terjeszkedett túl az irányelvben foglalt minimum követelményeken.

A határon átnyúló konstrukció fogalma megegyezik a belső piac múködését közvetlenül érintő adókikerülési gyakorlatok elleni szabályok megállapításáról szóló 2016/1164/EU irányelv (angol elnevezéssel: AntiTax Avoidance Directive, rövidítve: ATAD) 6. cikkében szereplő konstrukció fogalmával. Ennek megfelelően határokon átnyúló konstrukció ${ }^{12}$ az egynél több EU tagállamra, vagy egy EU tagállamra és egy harmadik országra vonatkozó olyan konstrukció, amely esetében a következő feltételek közül legalább egy teljesül:

- a konstrukció nem minden résztvevője ugyanabban az adójogrendszerben (államban, illetve területen) rendelkezik adóügyi illetőséggel;

\footnotetext{
10 CSABAI-ŐRY, 2019.

11 Erre példa a lengyel szabályozás, mely a belföldi ügyletekre is alkalmazni rendeli a kötelező jelentéstételt. A lengyel DAC 6 szabályozás ezen túlmenően a jelentéstételi kötelezettséget eredényező ismertetőjegyeket is szélesebb körben határozza meg, mint a DAC 6 irányelvben foglalt EU keretszabály.

12 LAKATOS, 2018.
} 
- a konstrukció egy vagy több résztvevôje egyidejüleg egynél több adójogrendszerben (államban, illetve területen) rendelkezik adóügyi illetőséggel;

- a konstrukció egy vagy több résztvevője másik adójogrendszerben (államban, illetve területen) folytat üzleti tevékenységet az ott található állandó telephelyén keresztül, és a konstrukció ezen állandó telephely üzleti tevékenységének egészét vagy részét képezi;

- a konstrukció egy vagy több résztvevője másik adójogrendszerben (államban, illetve területen) folytat tevékenységet anélkül, hogy ott adóügyi illetőséggel rendelkezne, vagy állandó telephelyet hozna létre;

- az ilyen konstrukció hatással lehet az automatikus információcserére, illetve a tényleges tulajdonosok azonosítására.

Egy konstrukció több lépésből vagy részből is állhat.

Az adatszolgáltatási kötelezettség akkor terjed ki egy konstrukcióra, ha az a DAC 6 szabályozásban meghatározott ismertetőjegyek legalább egyikével rendelkezik. Az egyes ismertetőjegyek öt fő kategóriába sorolhatók, ezek A, B, C, D, E megjelöléssel rendelkeznek, és az egyes kategóriákon belül további alkategóriák vannak. Az öt fó kategória az alábbiak szerint alakul: ${ }^{13}$

A. fő előny vizsgálatára irányuló teszthez kapcsolódó általános ismertetőjegyek;

B. fő előny vizsgálatára irányuló teszthez kapcsolódó különös ismertetőjegyek;

C. határon átnyúló ügyletekhez kapcsolódó különös ismertetőjegyek,

D. automatikus információcserére és a tényleges tulajdonlásra vonatkozó különös ismertetőjegyek, valamint

E. transzferárazással kapcsolatos különös ismertetőjegyek.

A DAC 6 irányelvben meghatározott ismertetőjegyek egy része esetén (A és B kategóriában, valamint a C kategória egyes alkategóriáiban) csak akkor szükséges adatszolgáltatás, ha előfeltételként teljesül a „fő előny vizsgálatára irányuló teszt”, vagyis az adott konstrukció megvalósítása nyomán észszerủen lehet számítani adóelőny elérésére. ${ }^{14}$ Más esetekben az

\footnotetext{
13 PAUKER, 2019.

14 A DAC 6 értelmében erre utalhat többek között az, ha (i) titoktartás övezi, hogyan érhető el a konstrukció alapján adóelőny; (ii) a tanácsadó díja az adóelőnyhöz igazodik, pl. jutalék, sikerdíj formájában; vagy (iii) előre szabványosított struktúrákról van szó, melyet jelentôsebb módosítás nélkül bármely adózó esetében fel lehet használni.
} 
ismertetőjegy fennállása önmagában megalapozza a jelentéstételi kötelezettséget. Annak eldöntése, hogy egy struktúra fő előnye vagy egyik fő előnye-e az adóelőny elérése, főszabályként azt lehet figyelembe venni, hogy a fő előny teszt megvalósul, ha a struktúrát feltehetően nem valósítanának meg, vagy más formában valósítanák meg, ha nem származna belőle adóelőny. ${ }^{15}$

Az ismertetőjegyek öt fő kategóriáján belül további alkategóriák léteznek. Ezek részletes ismertetésétôl eltekintünk, azonban a leglényegesebbeket kiemelve, jelentéstételi kötelezettség alá eshetnek különösen az alábbi konstrukciók:

- felvásárolnak egy veszteséges vállalatot, hogy a veszteséget az adókötelezettség csökkentésére használják fel, de tevékenységet nem folytatnak;

- a nyereséget tőkévé, ajándékká vagy más, alacsonyabb adókulcs, vagy mentesség alá eső bevétellé alakítják;

- olyan szervezeteket iktatnak be a struktúrába, melyek elsődleges kereskedelmi funkciót nem végeznek, céljuk körkörös tranzakciók megvalósítása révén az adóalap csökkentése;

- kapcsolt vállalkozások között végzett nyereségátcsoportosítási ügyletek, ahol a fő cél az adóelőny elérése;

- ugyanazon értékcsökkenési leírás érvényesítése egynél több adójogrendszerben; ugyanazon nyereség- vagy tőketételre kettôs adóztatás alóli mentesség érvényesítése egynél több adójogrendszerben;

- a pénzügyi számlainformációk automatikus cseréjét veszélyeztető, nem átlátható konstrukciók, vagy a tényleges tulajdonos megállapítását veszélyeztető konstrukciók.

Az említett konstrukciók tipikusan azt eredményezik, hogy költségeket kétszeresen számolnak el, kettős nem adóztatás áll fenn, jövedelmeket eltitkolnak vagy más jövedelemkategóriává alakítanak, vagy alacsony adókulcsú országokba csoportosítanak adóelőnyök elérése érdekében.

15 CSABAI-ŐRY, 2019. 


\subsection{A jelentéstételre kötelezettek és a határidők}

Ahogyan arról korábban említést tettünk, az adóhatóságok közötti információcsere azáltal valósulhat meg, hogy az ún. „adótervezésben közremúködők" előzetesen bejelentést tesznek az adóhatóságok felé, melyek aztán megosztják egymás között a kapott információkat.

A jelentéstételi kötelezettséget elsődlegesen az „adótervezésben közreműködő személy" köteles teljesíteni. Adótervezésben közreműködő személy az, aki kidolgozza, forgalmazza, megszervezi vagy végrehajtás céljából elérhetôvé teszi az adatszolgáltatási kötelezettség alá tartozó, határokon átnyúló konstrukciót, illetve irányítja annak végrehajtását (ún. közvetlen közremúködők). Ezek praktikusan jogi tanácsadók, könyvelők, adótanácsadók, adószakértők, üzleti tanácsadók lehetnek. Ugyanakkor, egy ügyletben részt vehetnek olyan közreműködők is, akik nem dolgozzák ki ugyan a konstrukciót, de segítséget nyújtanak annak megvalósításában (ún. közvetett közreműködők). A jelentéstételi kötelezettség rájuk is kiterjed, és minden egyes közremúködőnek azokról az elemekrôl kell jelentést tennie, amit még más nem jelentett.

Abban az esetben, ha nincs adótervezésben közremúködő egy konstrukcióban (pl. a multinacionális vállalkozás házon belül alakítja ki a konstrukciót), vagy olyan adótervezésben közremúködő van, aki nem köteles jelenteni (pl. EU-n kívüli, vagy titoktartásra tekintettel mentesül), akkor a bejelentés kötelezettsége az adózóra hárul. Mindez pontos koordinációt követel meg a konstrukcióban résztvevő valamennyi féltől.

Az adatszolgáltatás körébe tartozó információkat a tanácsadónak (illetve az adózónak) 30 napon belül kell bejelentenie az illetékes hatóságnak. A határidő számítása az alábbi időpontok közül a legkorábbitól kezdődik:

- azt a napot követő nap, amikor az adatszolgáltatási kötelezettség alá tartozó, határokon átnyúló konstrukció végrehajtás céljából elérhetővé vált; vagy

- azt a napot követő nap, amikor az adatszolgáltatási kötelezettség alá tartozó, határokon átnyúló konstrukció végrehajtásra kész; vagy

- az a nap, amikor az adatszolgáltatási kötelezettség alá tartozó, határokon átnyúló konstrukció végrehajtásának elsô lépésére sor került.

Bár a DAC 6 főszabályként 2020. július 1-étől alkalmazandó, a 2018. június 25-e után megvalósított tranzakciókat is - visszamenólegesen - be 
kell jelenteni. A magyar szabályozás sajátos átmeneti rendelkezéseket alkalmaz, mely szerint a 2018. június 25-e és 2020. június 30-a között végrehajtott ügyleteket 2021. február 28-áig kell jelenteni. Azokat a konstrukciókat, melyeket 2020. július 1. és 2020 december 31. között hajtottak végre, 2021. január 31-ig kell bejelenteni. 2021. január 1-ét követően megvalósított konstrukciók esetében az adatszolgáltatási határidők a fent leírtak szerint múködnek.

Egy-egy konstrukció kidolgozásában vagy végrehajtásában több közremúködő is részt vehet. Lényeges kérdés, hogy az adatszolgáltatási kötelezettséget mely tagállamban kell teljesíteni. E tekintetben az a fő irányvonal, hogy ha több hatóságnak kellene egyszerre információt szolgáltatni, akkor az alábbi listában az első helyen szereplő tagállam illetékes hatóságának kell bejelenteni a konstrukciót:

- az a tagállam, ahol az adótervezésben közremúködő adóügyi illetőséggel rendelkezik;

- az a tagállam, ahol az adótervezésben közremúködő olyan állandó telephellyel rendelkezik, amelyen keresztül a szóban forgó konstrukcióhoz kapcsolódó szolgáltatásokat nyúitja;

- az a tagállam, ahol az adótervezésben közremúködő be van jegyezve, illetve amely tagállam jogának hatálya alá tartozik;

- az a tagállam, ahol az adótervezésben közreműködő valamely jogi, adózási vagy tanácsadói szolgáltatásokkal kapcsolatos szakmai szövetség nyilvántartásában szerepel.

Bizonyos esetekben a DAC 6 lehetőséget ad arra, hogy az érintett mentesüljön az adatszolgáltatási kötelezettség alól. Többszörös adatszolgáltatási kötelezettség esetén a közreműködő mentesül a bejelentési kötelezettség alól, ha a nemzeti joggal összhangban bizonyítani tudja, hogy ugyanarról az információról egy másik tagállamban már bejelentést tett. Emellett bármely személy bizonyíthatja, hogy nem volt tudomása vagy tőle észszerűen nem volt elvárható, hogy tudomása legyen arról, hogy adatszolgáltatási kötelezettség alá tartozó, határokon átnyúló konstrukcióban vesz részt. A szabályozás értelmében a bizonyításkor hivatkozni lehet minden releváns tényre és körülményre, a rendelkezésre álló információkra, és az érintett személy konstrukcióval kapcsolatos szakértelmére és ismereteire.

A közreműködő és az adózó is mentesülhet a jelentéstételi kötelezettség alól, ha bizonyítja, hogy az adott információról egy 
közreműködő vagy másik adózó már teljesítette az adatszolgáltatási kötelezettséget.

A DAC 6 lehetôvé teszi a tagállamoknak, hogy mentességet adjanak az adótervezésben közreműködőknek, ha az adatszolgáltatási kötelezettség teljesítése nemzeti jogszabály által előírt titoktartási kötelezettség megsértését eredményezné. ${ }^{16}$ Ilyen esetben az adótervezésben közreműködőnek haladéktalanul értesítenie kell a többi közremúködőt, illetve közremúködő hiányában az érintett adózót, hogy ők kötelesek az adatszolgáltatási kötelezettséget teljesíteni. A magyar szabályozás is élt ezzel a lehetőséggel, így különösen pl. az ügyvédi titoktartásra tekintettel lehetôség van a mentesülésre a bejelentési kötelezettség alól. A mentesülő közvetítő köteles tájékoztatni a többi résztvevő közvetítőt, vagy az adózót, hogy a mentesülés folytán a bejelentés őket terheli.

\subsection{A jelentéstétel módja}

Az egyes tagállamok maguk alakítják ki azokat az eljárásokat, mely szerint a jelentéstételt meg kell tenni az adóhatóságok felé. A formanyomtatványok és azok tartalma tehát országonként változik, Magyarországon ezt a KONSTR megnevezésủ nyomtatvány szolgálja. A jelentéstételt rendszerint az adott ország hivatalos nyelvén kell megtenni.

A jelentéstétel keretében különösen az alábbi adatokat kell közölni az adóhatóságokkal, melyeket aztán az adóhatóságok automatikus információcsere keretében továbbítanak a konstrukcióval érintett többi adóhatóság felé: ${ }^{17}$

- az adótervezésben közremúködők és az érintett adózók azonosító adatai, ideértve nevüket, (természetes személyek esetén) születési idejüket és helyüket, adóügyi illetôségüket és adóazonosító számukat, valamint adott esetben azok a személyek, akik/amelyek az érintett adózóval kapcsolt vállalkozások;

- azon ismertetőjegyek részletes leírása, amelyek alapján a határokon átnyúló konstrukció adatszolgáltatási kötelezettség alá tartozik;

- az adatszolgáltatási kötelezettség alá tartozó, határokon átnyúló konstrukció tartalmi összefoglalása, amelynek keretében utalni kell a közismert nevére, amennyiben van ilyen, valamint leírást kell adni a

16 CSABAI-ŐRY, 2019.

${ }^{17}$ DAC 6, 8ab. cikk, (14) bekezdés 
szóban forgó gazdasági tevékenységekről vagy konstrukciókról, de csupán általános fogalmak használatával, anélkül, hogy a leírás kereskedelmi, gazdasági vagy szakmai titok, kereskedelmi eljárás, vagy olyan információ felfedésével járna, amelynek közlése sérti a közrendet;

- az az időpont, amikor az adatszolgáltatási kötelezettség alá tartozó, határokon átnyúló konstrukció végrehajtásának első lépésére sor került vagy sor fog kerülni;

- az adatszolgáltatási kötelezettség alá tartozó, határokon átnyúló konstrukció alapját képező nemzeti rendelkezések részletei;

- az adatszolgáltatási kötelezettség alá tartozó, határokon átnyúló konstrukció értéke;

- az adatszolgáltatási kötelezettség alá tartozó, határokon átnyúló konstrukció által érintett adózó(k) tagállamának, valamint a konstrukció által valószínűsíthetően érintett további tagállamok megnevezése;

- azon más tagállambeli személyek megnevezése, amelyeket az adatszolgáltatási kötelezettség alá tartozó, határokon átnyúló konstrukció valószínúleg érint, azoknak a tagállamoknak a megjelölésével, amelyekhez e személyek kapcsolódnak.

A jelentéstétel elmulasztása szankciót von maga után, az irányelvi szabályozás e tekintetben azt követeli meg a tagállamoktól, hogy a szankciók hatékonyak, arányosak legyenek, és visszatartó erővel rendelkezzenek. Ebből az következik, hogy a tagállamok saját hatáskörben dolgozzák ki a szankciórendszert. Egyes államokban ez súlyos büntetésmértékeket jelent. Magyarországon az adóhatóság az adatszolgáltatásra kötelezettet 500 ezer forintig terjedő mulasztási bírsággal sújthatja, ha adatszolgáltatási kötelezettségét hibásan, valótlan vagy hiányos adattartalommal, késve teljesíti, vagy azt elmulasztja. 5 millió forintig terjedő mulasztási bírság szabható ki, ha az adatszolgáltatásra kötelezett a kötelezettség teljesítésére való adóhatósági felhívás határidején belül nem, vagy nem jogszerūen teljesíti kötelezettségét. ${ }^{18}$

Az információk adóhatóságok közötti továbbítása már sztenderd módon, egységes rendszerben, erre rendszeresített formanyomtatvány segítségével történik. A tagállamok évenként tájékoztatják a Bizottságot az automatikus információcsere hatékonyságáról és gyakorlati eredményeiről.

18 AKTV. 43/Z. \(1)-(3) bekezdés 


\subsection{Az DAC 6 szabályozás gyakorlati alkalmazása tekintetében felmerülő legfőbb kérdések}

A DAC 6 szabályozás gyakorlati alkalmazása számos „szubjektív” elemet hordozó bizonytalansági tényezőt tartalmaz, melyek gyengíthetik az információcsere hatékonyságát. A szabályozás vizsgálata során különösen az alábbi kritikus kérdéseket azonosítottuk:

1. Mi minősül a végrehajtás első lépésének?

2. Hogyan kell értelmezni a fő előny tesztet?

3. Mire vezet a mentesülési lehetőségek eltérő meghatározása a tagállamokban?

4. Hogyan kell értelmezni az „észszerű elvárhatóságot” a kimentés során, és hogyan lehet ezt bizonyítani?

5. Milyen hatása lehet a tagállami szankciórendszerek eltéréseinek?

\subsubsection{A végrehajtás első lépése}

A határon átnyúló konstrukciók végrehajtásának első lépése több tekintetben is fontos. Egyrészt, azok a konstrukciók válhatnak jelentéskötelessé, melyek végrehajtása 2018. június 25-e után történt. Másrészt, adott esetben a végrehajtás első lépésétől kell számítani a 30 napos általános bejelentési határidőt.

A gyakorlatban többféleképpen értelmezhető, hogy mit kell egy konstrukció végrehajtásának első lépésének tekinteni. Lehet ez egy szerződés aláírása, egy új csoportvállalat megalapítása, vagy akár bármely lépésről történő döntéshozatal. Mivel a DAC 6 szabályozás nem tartalmaz erre konkrét iránymutatást, a jelentésre köteles személy saját értelmezésétől függhet a végrehajtás első lépésének megállapítása. A jogalkotó szándéka feltehetően az, hogy a legkorábbi időpont - tipikusan a döntéshozatal legyen a bejelentési kötelezettség kezdete, azonban ennek gyakorlati alkalmazása kérdéses.

\subsubsection{A fő előny teszt értelmezése}

$\mathrm{Az}$ ismertetőjegyek egy részénél a bejelentési kötelezettség fennállásának megállapításához azt is vizsgálni kell, hogy a struktúra létrehozásának elsődleges célja volt-e az adóelőny elérése, azaz megvalósult- 
e a fó előny teszt. Ahogyan korábban említettük, a fó előny teszt vizsgálatakor az lehet a fő elhatárolási szempont, hogy az adott struktúrát létrehozták volna-e akkor is, ha nem származik belőle adóelőny. A gyakorlatban ugyanakkor ennek megállapítása nem egyértelmü, hiszen az adózóknak joga van ahhoz, hogy úgy alakítsák a struktúrát, hogy a számukra adózási szempontból kedvezőbb eredmény érjék el. A tagállami jogalkalmazás során eltérő lehet egye-egy struktúra megítélése, és ez nehezíti a bejelentésre kötelezettek munkáját. A bejelentésre kötelezett közremúködők tekintetében ez két irányú viselkedést válthat ki: előfordulhat „túljelentés”, ha a közremúködők óvatosságból inkább arra az álláspontra helyezkednek, hogy bizonytalanság esetén bejelentést tesznek, még akkor is, ha a fô elôny teszt nem egyértelműen igazolható. Előfordulhat ugyanakkor ennek az ellenkezője is, ha a közreműködő inkább nem tesz bejelentést, ha nem tudja kétséget kizáróan azt bizonyítani, hogy az adózó elsődleges célja az adóelőnyök elérése volt.

\subsubsection{Mentesülési lehetőségek eltérő alkalmazása}

A DAC6 szabályozás elsősorban az adótervezésben közreműködő piaci szereplők, azaz a bankok, adótanácsadó cégek, ügyvédi irodák stb. részére ír elő adatszolgáltatási kötelezettséget az adóhatóság felé. Ezen közremúködők esetében sokszor saját nemzeti szabályozásuk alapján szakmai titoktartás érvényesül. A DAC 6 különösen erre tekintettel teszi lehetővé a tagállamoknak, hogy mentességet adjanak az adótervezésben közreműködőknek, ha az adatszolgáltatási kötelezettség teljesítése nemzeti jogszabály által előírt titoktartási kötelezettségük megsértését eredményezné. ${ }^{19}$ Mentesülés esetén a bejelentési kötelezettség a következő közvetítőt, végső soron pedig az adózót terheli.

Egyes tagállamok, köztük Magyarország is, éltek a DAC 6 biztosította lehetőséggel, míg más tagállamok nem. Amikor egy adott határon átnyúló konstrukcióban sok különböző országban résztvevő (adótervezésben közremúködő és érintett adózó) van, megjegyezve, hogy ez a tipikus, akkor gyakorlati nehézséget okozhat annak megállapítása, hogy egyes közvetítők esetén mely országban, kinek, milyen adatra kell jelentést tennie. Az is előfordulhat, hogy egyes résztvevők igyekeznek olyan országba

${ }^{19}$ CSABAI-ŐRY, 2019. 
csoportosítani a bejelentési kötelezettséget, ahol kedvezőbb mentességi lehetőségek érvényesülnek.

A mentesülési lehetőségek között szerepel az is, hogy ha valamelyik résztvevő az adott konstrukció tekintetében már bejelentést tett (ugyanabban a tagállamban vagy máshol), akkor a másik közremúködőnek nem kell bejelentést tennie. A szabályozás nem tartalmaz ugyanakkor egységes iránymutatást arra, hogy hogyan kell ezt igazolni. A DAC 6 szabályozás annyi kitételt tartalmaz, hogy a bizonyítást „a nemzeti joggal összhangban” kell megtenni. Kérdés, hogy adott esetben elegendő lehet-e a másik résztvevő nyilatkozata arról, hogy a bejelentést megtette, vagy a mentesülésre hivatkozó közreműködőnek részletes információval kell-e rendelkeznie a konkrét bejelentést tartalmáról. Ennek a kérdésnek az egységes szabályozása elengedhetetlen lenne a hatékony jogalkalmazás, és a bejelentésre kötelezettek jogainak védelme érdekében.

\subsubsection{Kimentés és „észszerű elvárhatóság”}

Az irányelv értelmében bármely személy bizonyithatja, hogy nem volt tudomása vagy tőle észszerūen nem volt elvárható, hogy tudomása legyen arról, hogy adatszolgáltatási kötelezettség alá tartozó, határokon átnyúló konstrukcióban vesz részt.

A szabályozás ezen kritériuma is számos bizonytalanságra vezethet, hiszen a bizonyítás - és az adóhatósági ellenbizonyítás - során bármely releváns tényt, körülményt, rendelkezésre álló információt fel lehet használni. Különösen nehéz az „észszerűen nem volt elvárható” kritérium értelmezése, mivel ez szubjektívvé teheti az adóhatósági jogalkalmazást. Kérdés az is, hogy egy adótervezésben közreműködő mennyiben hivatkozhat saját szakértelmére vagy annak hiányára egy adott konstrukcióval kapcsolatban. Előfordulhat például, hogy egy közvetett közremúködő, aki a struktúra kialakításában nem vesz részt, de ahhoz kiegészítő szolgáltatást nyújt, nem látja át az összetett konstrukciót és az abból eredô adóelőnyöket. Hivatkozhat-e vajon ilyen esetben a nem elvárhatóságra, vagy köteles részletesen vizsgálni az összetett ügyletet?

A „észszerű elvárhatóság” kritériuma a szankciórendszer tekintetében is előkerül. A magyar szabályozás alapján nincs helye mulasztási bírság kiszabásának, ha az adatszolgáltatásra kötelezett mulasztását, késedelmét, hibás, valótlan tartalmú vagy hiányos teljesítését annak igazolásával menti ki, 
hogy úgy járt el, ahogy az az adott helyzetben általában elvárható. A kritérium értelmezése szintén szubjektív lehet az adóhatósági gyakorlatban.

\subsubsection{A tagállami szankciórendszerek eltérései}

Az irányelvi szabályozás a szankciórendszer kialakítása tekintetében csak azt várja el a tagállamoktól, hogy a szankciók hatékonyak, arányosak, és kellően visszatartó erejűek legyenek. Ennek megállapítása teljes mértékben tagállami hatáskör, és vannak olyan tagállamok, ahol több millió eurós összegű jogkövetkezményeket helyeznek kilátásba. A tagállami szabályozások rendkívül eltérőek.

Felmerül a kérdés, hogy a szankciórendszerekben történő eltérések vezethetnek-e ahhoz, hogy a jelentési kötelezettséget egyes országokban inkább nem teljesítik, vagy elindul egy ún. „treaty shopping” a kedvezőbb szankciórendszert alkalmazó országok irányába.

A bejelentésre kötelezettek védelmét szolgálná, ha egységes szankciórendszer érvényesülne a bejelentési kötelezettség megsértése esetén.

\subsection{Következtetések, szükséges lépések a hatékonyság biztosítása érdekében}

Ahogyan az előző fejezetben bemutattuk, a szabályozásban sok a bizonytalansági tényező, ami a hatékonyságot rontja abban a tekintetben, hogy az adóhatósághoz nem feltétlen jutnak el, vagy nem megfelelően a kívánt információk. A szabályozási kérdések a bejelentésre kötelezettek tekintetében is jogalkalmazási bizonytalanságot szülnek, és növelik a jogszabályi megfelelés költségeit.

A DAC 6 szabályozás teljesítése az egyes határon átnyúló konstrukciókban résztvevő szereplők szoros együttmúködését igényli, ahol minden egyes szereplőnek (közvetlen, közvetett közreműködőnek, érintett adózónak) ugyanúgy kell értelmeznie és értékelnie egy adott tranzakciót, de eltérő tagállamokban, eltérő nemzeti szabályozás és nemzeti adóhatósági jogalkalmazás fényében kell teljesítenie a „compliance” feladatokat. A gyakorlatban az egységes kezelés jogszabályi megfelelés szintjén tehát múködik, mivel minden egyes résztvevőnek saját tagállami szabályai szerint kell vizsgálnia a helyi követelményeknek való megfelelést, ami sokszoros adminisztrációval, és jelentős költségekkel jár az egyes szereplőkre nézve. Ugyanazon konstrukció tekintetében tehát az egyes közreműködők, és az 
összes érintett adózó is el kell végezze a bejelentési kötelezettség fennállásának, illetve az esetleges kimentési lehetőségeknek vizsgálatát, és mindezt megfelelően kell dokumentálnia, ha el kívánja kerülni a tagállami szankciókat. Mindez a DAC 6 szabályozást az érintett gazdasági szereplők számára rendkívül költségessé teszi.

Megoldást az jelentene, ha egyértelműen, egységes módon, a közösségi szabályozásban kerülnének rögzítésre a kiemelt kérdések, így az, hogy mit kell a végrehajtás első lépése alatt érteni, hogyan kell a fő elóny tesztet értelmezni, milyen egységes szabályok vonatkoznak a mentesülésre, kimentésre, szankciókra. Csak egységes szabályozás révén lehet az információcsere hatékonyságát, és a bejelentésre kötelezettek hatékony jogvédelmét biztosítani.

\section{KONKLÚZIÓ}

A DAC 6 szabályozás újabb fontos előrelépést jelent a nemzetközi szintű adóelkerülés visszaszorítására, és illeszkedik az automatikus adóügyi információcsere kiterjesztésére irányuló törekvések láncolatába.

A szabályozás elsősorban az adótervezésben közremúködőkre (adótanácsadók, ügyvédek, pénzügyi szolgáltatók) hárít bejelentési kötelezettséget, végső soron pedig az érintett adózóktól követeli meg az adóhatóság felé az információszolgáltatást. Az adóhatóságok automatikusan továbbítják egymás felé a kapott információkat.

A jelentéstétel követelményeiben több olyan bizonytalansági tényező van, melyek nehezítik a gyakorlati alkalmazást, és a hatékonysággal szemben hatnak. Ilyen kérdések a struktúra végrehajtásának kezdő időpontjában rejlő bizonytalanság, a fő előny teszt értelmezése, a mentesülési lehetőségek eltérő tagállami megállapítása, az „ésszerūen elvárhatóság” kritériumának beépítése a szabályozásba, valamint a tagállami szankciórendszerekben rejlő eltérések. Ezen szabályozási elemek egyértelmű és egységes meghatározása jelentősen elősegítené a hatékonyságot, és elengedhetetlen a bejelentési kötelezettség alanyainak a jogvédelme érdekében is.

A DAC 6 alapján történő információcsere mindezzel együtt fontos új lehetőséget jelent az adóhatóságok számára, mivel valós időben információt szerezhetnek a nemzetközi adótervezési struktúrákról, és szüksége esetén a tagállami anyagi jogi szabályozás módosításával megelőzhetik a visszaéléseket, vagy káros gyakorlatokat. Az automatikus információcsere keretében kapott adatokat az adóhatóságok kockázatelemzés során is 
felhasználhatják. Nemzetközi tendencia az, hogy az adóhatóságok egyre nagyobb hatékonysággal dolgozzák fel és elemzik a rendelkezésükre álló egyre szélesebb körű adatvagyont. Az információcsere kiterjesztése a határon átnyúló konstrukciókra tovább szélesíti a kockázatelemzés alapjául használható adatok körét az adóhatóságok számára.

\section{FELHASZNÁLT IRODALOM}

2013. évi XXXVII. törvény az adó- és egyéb közterhekkel kapcsolatos nemzetközi közigazgatási együttmúködés egyes szabályairól

A TANÁCS 2011/16/EU IRÁNYELVE az adózás területén történő közigazgatási együttműködésről és a 77/799/EK irányelv hatályon kívül helyezésérôl, HL L 64, 2011.3.11.

A TANÁCs 2015/2376 IRÁNYELVE a 2011/16/EU irányelvnek az adózás területére vonatkozó kötelező automatikus információcsere tekintetében történő módosításáról, HL L 332, 2015.12.18.

A TANÁCS 2016/881/EU IRÁNYELVE a 2011/16/EU irányelvnek az adózás területére vonatkozó kötelező automatikus információcsere tekintetében történő módosításáról

A TANÁCS (EU) 2018/822 IRÁNYELVE a 2011/16/EU irányelvnek az adatszolgáltatási kötelezettség alá tartozó, határokon átnyúló konstrukciókkal kapcsolatosan az adózás területére vonatkozó kötelező automatikus információcserére vonatkozó előírásainak módosításáról

CSABAI RÓBERT-ÔRY TAMÁs (2019): A határokon átnyúló konstrukciókkal kapcsolatos új uniós szabályozás, Adó szaklap, Budapest, 2019/1-2.

LAKATOS ZSUZSA (2018): Elérhetô: https://5percado.hu/adotervezesadatszolgaltatasi-kotelezettseg-1-resz/ (Letöltve: 2020.10.10.)

MANUAL ON THE IMPLEMENTATION OF EXCHANGE OF INFORMATION FOR TAX Purposes (2006), III. Modul az automatikus információcseréről; OECD

PAUKER ZOLTÁN (2019): Jelentéstételi kötelezettség agresszív adóstruktúrák esetén,

Elérhetô: https://adozona.hu/altalanos/Agressziv adostrukturak jelentesteteli ko te R7DVFQ (Letöltve: 2020.10.10.)

OECD (2012): Automatic Exchange of Information, What it is, How it works, Benefits, What remains to be done, 23/7/2012., 19. o.

ŐRY TAMÁs (2016): Az Európai Unió adómegállapítási jogsegély irányelve, Budapest, Adó szaklap, Budapest, 2016/12-13. 
VARGA ERZSÉBET (2019): Az automatikus adóügyi információcsere alkalmazása Magyarországon; In: Halász, Zsolt (szerk.) Magistra et Fautrix - Halustyik Anna emlékére; Budapest, Magyarország: Pázmány Press 